\title{
DIET AND REPRODUCTION OF LARGEMOUTH BASS \\ IN A RECENTLY INTRODUCED POPULATION, LAKE BRACCIANO (CENTRAL ITALY)
}

\author{
A. MARINELLI (1), M. SCALICI (2)^ AND G. GIBERTINI (3)
}

Università degli Studi "Roma Tre", Dipartimento di Biologia, viale G. Marconi 446, 00146 Roma, Italy.

(1) andreamarinelli@hotmail.com

(2) * corresponding author: scalici@uniroma3.it

(3) gibertin@uniroma3.it

Reçu le 18 septembre 2006

Accepté le 28 mai 2007

Received September 18, 2006

Accepted May 28, 2007

\begin{abstract}
This paper concerns a study of some aspects of largemouth bass ecology in an Italian lake (Lake Bracciano). We assessed the success and possible impact of its recent introduction (1998) upon the fish community. From October 2001 to September 2002, 162 individuals were caught, measured, aged and submitted to biopsy (stomach and gonads were removed). Four age classes, from $0+$ to $3+$, were observed in the population. Largemouth bass feeding activity was high in June, mostly eating fish (55.7\%), crustaceans (in particular Palaemonetes antennarius, $37.5 \%)$, insects (4.5\%) and molluscs $(2.3 \%)$. The G.S.I. values showed an autumnal breeding period (from December to February) rather than the spring-summer one frequently described in North America. Moreover, bass attained sexual maturity during the second year of life $(1+)$. These differences could be related to its recent introduction and the apparent success could represent a problem for other species in the Lake.
\end{abstract}

Key-words: Micropterus salmoides, largemouth bass, alien species, diet, reproduction, Central Italy.

\section{RÉGIME ALIMENTAIRE ET REPRODUCTION DU BLACK-BASS DANS UNE POPULATION RÉCEMMENT INTRODUITE, LAC BRACCIANO (ITALIE CENTRALE)}

\section{RÉSUMÉ}

Cet article relate une étude de certains aspects de l'écologie du black-bass à grande bouche, Micropterus salmoides, dans un lac italien (Lac Bracciano). Nous avons évalué le succès de cette introduction récente (1998) et son impact possible sur la communauté piscicole. D'octobre 2001 à septembre 2002, 162 individus ont été prélevés, mesurés, et leur âge évalué avant biopsie de l'estomac et des gonades. Quatre classes d'âge, de $0+$ à 3 + ont été observées dans la population. On note une activité prédatoire élevée en juin, avec une alimentation constituée essentiellement de poissons $(55,7 \%)$, de crustacés (en particulier Palaemonetes antennarius, 37,5\%), d'insectes (4,5\%) et de mollusques $(2,3 \%)$. Ceci nous laisse penser qu'il existe un possible chevauchement de trophisme du black-bass à grande bouche avec la perche commune, Perca fluviatilis, et le brochet, 
Esox lucius. Les valeurs de I'I.G.S. ont montré que la période de reproduction a lieu de décembre à février plutôt qu'en printemps-été, comme cela est plus fréquemment décrit en Amérique du Nord, et qu'elle pourrait durer plus de trois mois. De plus, la maturité sexuelle semble être atteinte durant la deuxième année $(1+)$. La récente introduction du blackbass ne permet pas de prévoir ses effets sur la communauté lacustre, mais le succès de sa prédation et de sa reproduction ainsi que l'absence de prédateurs naturels pourraient accélérer l'acclimatation du black-bass dans les eaux intérieures de l'Italie centrale.

Mots-clés : Micropterus salmoides, black-bass à grande bouche, espèce allochtone, régime alimentaire, reproduction, Italie Centrale.

\section{INTRODUCTION}

Many species introductions can be beneficial to humans (EWEL et al., 1999) or cause minimal environmental impacts (WILLIAMSON and FITTER, 1996; JERSCKE and STRAYER, 2005), but non-indigenous species are often capable of dominating native populations and communities (KOLAR and LODGE, 2001; CROOKS, 2002). This factor creates a risk of general alteration of the biological diversity through the homogenisation of the ecosystems (MACK et al., 2000; RAHEL, 2000).

In Italy, in the past 20 years, we have observed a rapid increase in exotic fish, today totalling 40 species (38\%) from a total of 105 (MAIO, 2002). Among these taxa, largemouth bass, Micropterus salmoides Lacépède, 1802, a North-American Centrarchidae, introduced outside its native range for fishing purposes in several countries worldwide (LADIGES and VOGT, 1979), and is now estimated to be among the top 5 species introduced worldwide into inland waters (WELCOMME, 1992). Its first occurrence in Italy was recorded at the beginning of the $20^{\text {th }}$ century (TORTONESE, 1975), spreading successively throughout the entire national territory (ZERUNIAN, 2002), Latium included (ZERUNIAN, 1980; BELLINI et al., 2001; CLERICl et al., 2007; GIBERTINI et al., 2004; MARINELLI et al., 2004).

Largemouth bass is a lake-dwelling species, preferring marshy environments and shallow waters (HICKLEY et al., 1994). It has been described as a piscivorous fish (HEIDINGER, 1974; CARLANDER, 1977), although a shift in diet usually occurs in relation to size and age (GARCIA-BERTHOU, 2002). In fact, after an early diet of zooplankton and insects (KEAST and WEBB, 1966; HEIDINGER, 1976; KEAST, 1985; PHILLIPS et al., 1995) M. salmoides begins eating fish usually at $50-70 \mathrm{~mm}$ standard length (PHILLIPS et al., 1995; OLSON, 1996), quickly (at $80-100 \mathrm{~mm}$ of SL) becoming exclusively piscivorous in the presence of available prey (CARLANDER, 1977; WERNER et al., 1977; KEAST, 1985). Other studies carried out in Central Italy have shown low growth rates (ZERUNIAN, 1980; ALESSIO, 1981 and 1983; LORENZONI et al., 2002a) and a reproductive period occurring between May and July (January-April in Umbria, Central Italy - LORENZONI et al., 2002b), when the females spawn several eggs many times due to their asynchronous ovary (BREDER and ROSEN, 1966; TORTONESE, 1975; ALESSIO, 1983).

The present study was carried out to evaluate some aspects of the reproduction and diet of a M. salmoides population recently introduced into an Italian lake (Lake Bracciano; first record in 1998 - MARINELLI et al., 2004), in order to assess its acclimatization grade and to ascertain the possible impact on the indigenous fish community.

\section{MATERIALS AND METHODS}

\section{Study area}

Lake Bracciano, situated among the Sabatini Mountains near Rome (between $42^{\circ} 10^{\prime}$ and $42^{\circ} 05^{\prime} \mathrm{N}$ and between $12^{\circ} 10^{\prime}$ and $12^{\circ} 17^{\prime} \mathrm{E}$, at $164 \mathrm{~m}$ a.s.I.), measures $57.2 \mathrm{~km}^{2}$, 
with a perimeter of $31.5 \mathrm{~km}$. It is of volcanic origin with basically oligotrophic water. The surface water temperature $(0-4 \mathrm{~m})$ varied from a minimum of $8^{\circ} \mathrm{C}$ in winter to a maximum of $26^{\circ} \mathrm{C}$ in summer. The aquatic plants were constituted mainly by Characeae and secondarily by other macrophytes such as Potamogeton perfoliatus, Potamogeton lucens, Vallisneria spiralis, Myriophyllum spicatum and Ceratophyllum demersum. The fish community included the following species: Esox lucius, Perca fluviatilis, Tinca tinca, Scardinius erythrophthalmus, Rutilus rubilio, Cyprinus carpio, Carassius auratus, Mugil cephalus, Lepomis gibbosus, Anguilla anguilla, Atherina boyeri and Coregonus lavaretus (GIBERTINI et al., 2004).

\section{Sampling and data analysis}

The sampling was carried out monthly from October 2001 to September 2002 by trawling professional dragnets (with $2 \mathrm{~cm}$ mesh-size) at sunset. The fish were aged (by scale reading - according to BAGLINIERE and LE LOUARN, 1987), measured (standard length, SL) and weighted (total weight, $\mathrm{W}_{\mathrm{T}}$ ). Then, immediately, the stomach and the gonads were removed.

The condition coefficient $\left(k_{c}\right)$ was calculated by the following formula:

$$
\mathrm{k}_{\mathrm{c}}=\mathrm{W}_{\mathrm{T}} / \mathrm{SL}{ }^{\mathrm{b}}
$$

where $b$ was a specific constant representing the angular coefficient of the relationship.

$$
\ln \mathrm{W}_{\mathrm{T}}=\mathrm{b} \operatorname{lnSL}+\ln \mathrm{k}_{\mathrm{c}}
$$

Concerning the diet analysis, the vacuity index $(\mathrm{V})$ was calculated as:

$$
\mathrm{V}=\left(\mathrm{St}_{\mathrm{v}} / \mathrm{St}\right) 100
$$

where $\mathrm{St}_{\mathrm{v}}$ indicated the number of empty stomachs and St the total number of stomachs. Then, the gastric contents were observed in order to evaluate the feeding strategy, the importance of a prey, and the size of the trophic niche. To do this, we used the COSTELLO (1990) diagram method (modified by AMUNDSEN et al., 1996), which relates the preyspecific abundance $\left(P_{j}\right)$ to the occurrence frequency $\left(O_{i}\right)$, given respectively by the following functions:

$$
\begin{gathered}
P_{i}=\left(S S_{i} / S S_{t i}\right) 100 \\
O_{i}=\left(J_{i} / N\right) 100
\end{gathered}
$$

where: $S_{i}$ indicated the abundance of the prey $i$ in the stomachs; $S_{t i}$ the total prey abundance in the stomachs containing the prey $i ; J_{i}$ was the stomach number containing the specific prey $i$; $\mathrm{N}$ the number of stomachs containing preys.

The gonads were removed in order to sex every animal (since $M$. salmoides has no sexual dimorphism - ALESSIO, 1981) and weighed to calculate the gonadic index:

$$
\text { G.I. }=\left[W_{G} /\left(W_{T}-W_{G}\right)\right] \cdot 100
$$

where $W_{G}$ represents the weight of the gonads and $W_{T}$ the total weight of the fish. Then, both female and male gonads were fixed in a Bouin solution and later used for histologic observation, upon dehydration, paraffin inclusion, microtome cut and Emallume-Eosina staining. In order to relate the gonadic tissue development phase to the sampling month, the Monthly Average Level Index (M) was calculated:

$$
\mathrm{M}=(\mathrm{S} F) / \mathrm{N}_{\text {tot }}
$$

where $\mathrm{F}$ is the value attributed to every phase (Table I) and $\mathrm{N}_{\text {tot }}$ the total specimen number. Moreover, the sexual maturity size was estimated calculating the length at which $50 \%$ of the specimens reach the full maturity phase (i.e. $L_{50 \%}$, see SPEDICATO and CANNAS, 2000). 


\section{Table I}

Gonadic development phases and respective attributed values (F), by NIKOLSKY (1963) modified.

\section{Tableau I}

Phases de développement gonadique et valeurs respectives $F$ attribuées, par NIKOLSKY (1963) modifié.

\begin{tabular}{|lc|lc|}
\hline Male phases & F value & Female phases & F value \\
\hline $\begin{array}{l}\text { Initial maturity phase; none } \\
\text { or few mature spermatozoa; } \\
\text { primary spermatids. }\end{array}$ & 1 & $\begin{array}{l}\text { Quiescent gonad; occurrence of } \\
\text { oogonia only. }\end{array}$ & 1 \\
\hline $\begin{array}{l}\text { Intermediate maturity; few } \\
\text { mature spermatozoa observed; } \\
\text { secondary spermatids. }\end{array}$ & 2 & $\begin{array}{l}\text { Initial phase of previtellogenesis; } \\
\text { some egg cells in perinucleolar } \\
\text { phase. }\end{array}$ & 2 \\
\hline $\begin{array}{l}\text { Advanced maturity; more than } \\
\text { half of the histologic section is } \\
\text { rich in mature spermatozoa. }\end{array}$ & 3 & $\begin{array}{l}\text { Advanced previtellogenesis; } \\
\text { many cells in perinucleolar } \\
\text { phase. }\end{array}$ & 3 \\
\hline $\begin{array}{l}\text { Mature gonad; most of the } \\
\text { tissue observed is rich in mature } \\
\text { spermatozoa. }\end{array}$ & 4 & $\begin{array}{l}\text { lnitial vitellogenesis; few } \\
\text { cytoplasmic lipidic drops; } \\
\text { increasing cell size. }\end{array}$ & 4 \\
\hline $\begin{array}{l}\text { Empty gonad; sperm absent; } \\
\text { lacunose areas. }\end{array}$ & - & $\begin{array}{l}\text { Advanced vitellogenesis phase; } \\
\text { mature eggs rich in cytoplasmic } \\
\text { lipid drops. }\end{array}$ & 5 \\
\hline
\end{tabular}

\section{RESULTS}

\section{Population analysis}

The whole sample was composed of 162 specimens (Table II), 91 males (56.2\%) and 71 females $(43.8 \%)$, with a $0.8: 1$ sex ratio $(F: M)$, not different from $1: 1\left(\chi^{2}=2.44\right.$; $\mathrm{gl}=1 ; \mathrm{ns}$ ). Each of the four observed age classes (from $0+$ to $3+-$ see Figure 1 ) showed a sex ratio in favour of the males, but there were no significant differences in $1+$ and $2+$ classes (0.8:1 and 0.9:1, respectively), while the female/male ratio for the classes $0+$ and $3+$ was significantly different from $1: 1\left(0.3: 1\right.$ and $1.3: 1$, respectively $-\chi^{2}=8.02 ; \mathrm{gl}=3$; $\mathrm{p}<0.05)$.

The slope of the regression between the standard length and the total weight were 3.03 and 3.09, respectively, for the females and the males, and the average values for the condition coefficient were 0.023 for the females and 0.019 for the males. The monthly values of the condition coefficient for both sexes are shown in Figure 2.

\section{Feeding strategy}

A total of $108(66.7 \%)$ largemouth bass contained prey remains within the stomach. Figure 3 shows the monthly mean values of the vacuity index for the males and the females. Preys consisted of fish (55.7\% of the full stomachs - cf. Figure 5), decapods (i.e. Palaemonetes antennarius, $37.5 \%)$, insects $(4.5 \%)$ and molluscs $(2.3 \%)$. Crustaceans were more abundant in late winter and spring, whereas fish were the most abundant preys in summer (Figure 4). Insects occurred in autumn, spring and summer, while the molluscs occurred in summer and winter. 


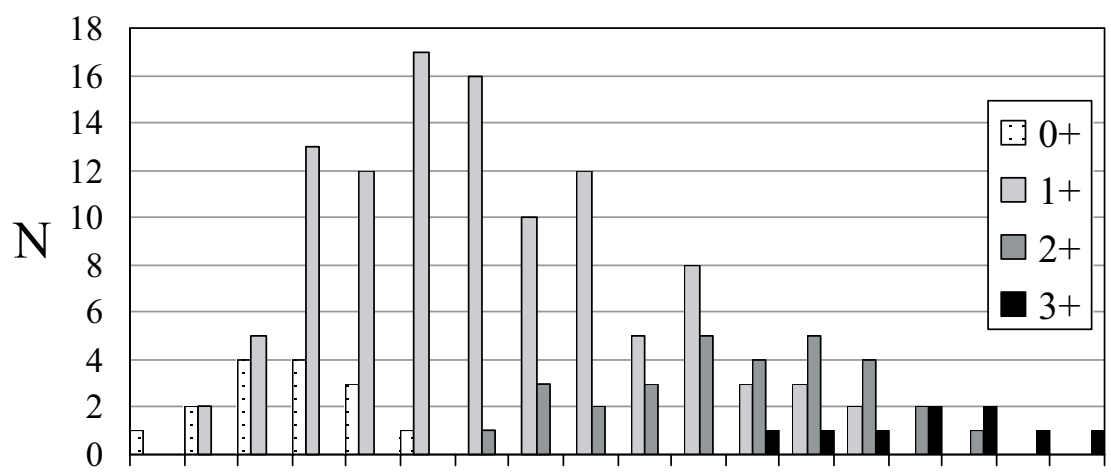

$\begin{array}{llllllllllllllllll}13 & 14 & 15 & 16 & 17 & 18 & 19 & 20 & 21 & 22 & 23 & 24 & 25 & 26 & 27 & 28 & 29 & 30\end{array}$

$\mathrm{SL}(\mathrm{cm})$

Figure 1

Length-frequency diagram of the studied sample for the different age-classes (SL: standard length; N: number of specimens in a given size-class for a given age class).

Figure 1

Diagramme de distribution des effectifs échantillonnés, par classes de taille, pour les différentes classes d'âge de l'échantillon étudié (SL : longueur standard ; $\mathrm{N}$ : nombre de spécimens d'une classe de taille donnée pour une classe d'âge donnée).

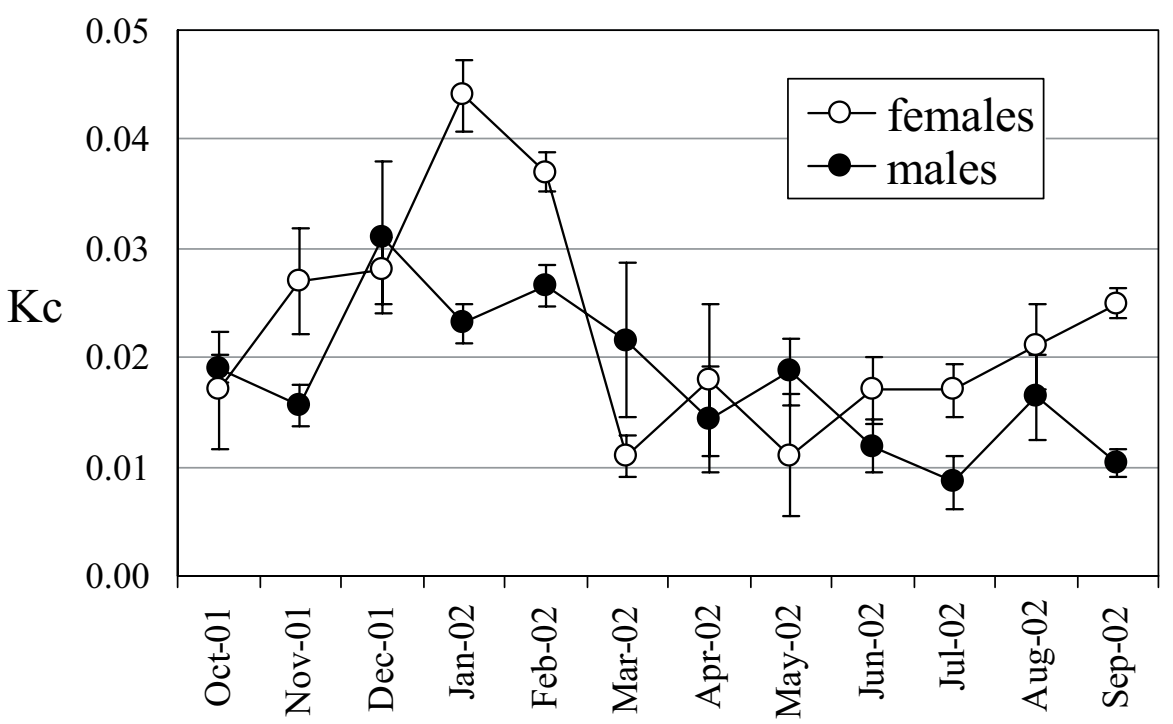

Figure 2

Mean monthly values and standard deviations of the condition coefficient $\left(k_{c}\right)$ of the largemouth bass specimens caught during the study.

Figure 2

Moyennes mensuelles et déviations standard du coefficient de conditions $\left(\mathbf{k}_{\mathrm{c}}\right)$ des spécimens de black-bass capturés pendant l'étude. 


\section{Table II}

Morphometric parameters.

\section{Tableau II}

Paramètres morphométriques.

\begin{tabular}{|cccc|cccc|cccc|}
\hline & & & \multirow{4}{*}{ Age } & \multicolumn{4}{|c|}{ Standard Length } & \multicolumn{4}{c|}{ Weight } \\
& Sex & $\mathrm{n}$ & $\begin{array}{c}\text { Sex } \\
\text { ratio }\end{array}$ & Mean & St. dev. & Max & Min & Mean & St. dev. & Max & Min \\
\hline \multirow{2}{*}{$0+$} & $\mathrm{F}$ & 4 & \multirow{2}{*}{$0.3: 1$} & 16.5 & 0.5 & 16.9 & 13.4 & 99.8 & 10.6 & 111.9 & 92.2 \\
& $\mathrm{M}$ & 11 & & 15.7 & 0.9 & 18.1 & 14.1 & 84.6 & 13.3 & 104.4 & 63.3 \\
\hline \multirow{2}{*}{$1+$} & $\mathrm{F}$ & 48 & \multirow{2}{*}{$0.8: 1$} & 21.7 & 4.5 & 26.8 & 14.2 & 270.5 & 147.5 & 527.4 & 56.8 \\
& $\mathrm{M}$ & 60 & & 22.3 & 4.4 & 26.3 & 14.7 & 277.9 & 142.8 & 474.7 & 58.0 \\
\hline \multirow{2}{*}{$2+$} & $\mathrm{F}$ & 14 & \multirow{2}{*}{$0.9: 1$} & 24.3 & 3.9 & 28.4 & 21.3 & 226.2 & 164.5 & 712.3 & 101.2 \\
& $\mathrm{M}$ & 16 & & 25.2 & 3.8 & 27.6 & 19.5 & 286.3 & 130.1 & 459.7 & 97.2 \\
\hline \multirow{2}{*}{$3+$} & $\mathrm{F}$ & 5 & \multirow{2}{*}{$1.3: 1$} & 25.6 & 2.3 & 30.0 & 24.3 & 224.7 & 49.1 & 259.4 & 189.9 \\
& $\mathrm{M}$ & 4 & & 27.1 & 0.6 & 29.3 & 25.8 & 348 & 35.4 & 373.0 & 323.0 \\
\hline
\end{tabular}

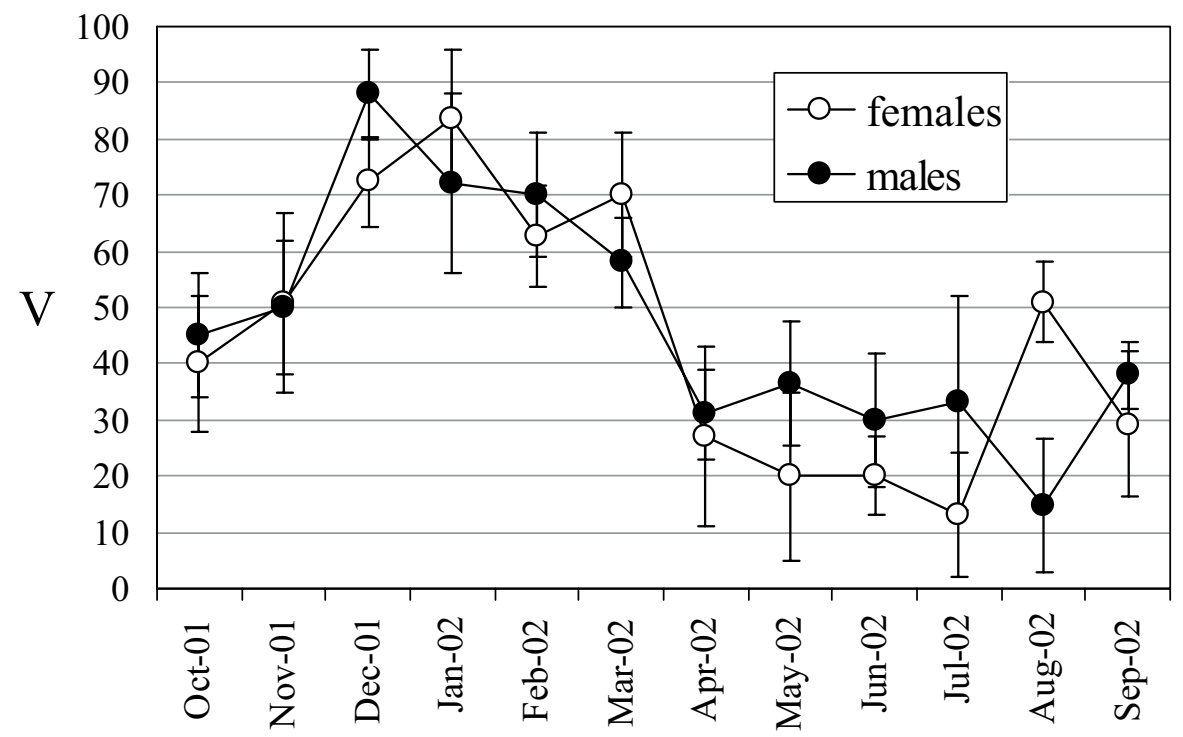

Figure 3

Mean monthly values and standards deviation of the vacuity index (V) of the largemouth bass specimens caught during the study.

\section{Figure 3}

Moyennes mensuelles et déviations standard de l'index de vacuité (V) des spécimens de black-bass capturés pendant l'étude.

The most frequent fish prey found in the stomach contents $(0.92)$ was the big-scaled sandsmelt (Figure 5) whereas young pike was the rarest (0.2). The other fish species (Salaria fluviatilis, Lepomis gibbosus, Micropterus salmoides j., Coregonus lavaretus j., Perca fluviatilis j.) showed a low frequency of occurrence in the stomach contents. 


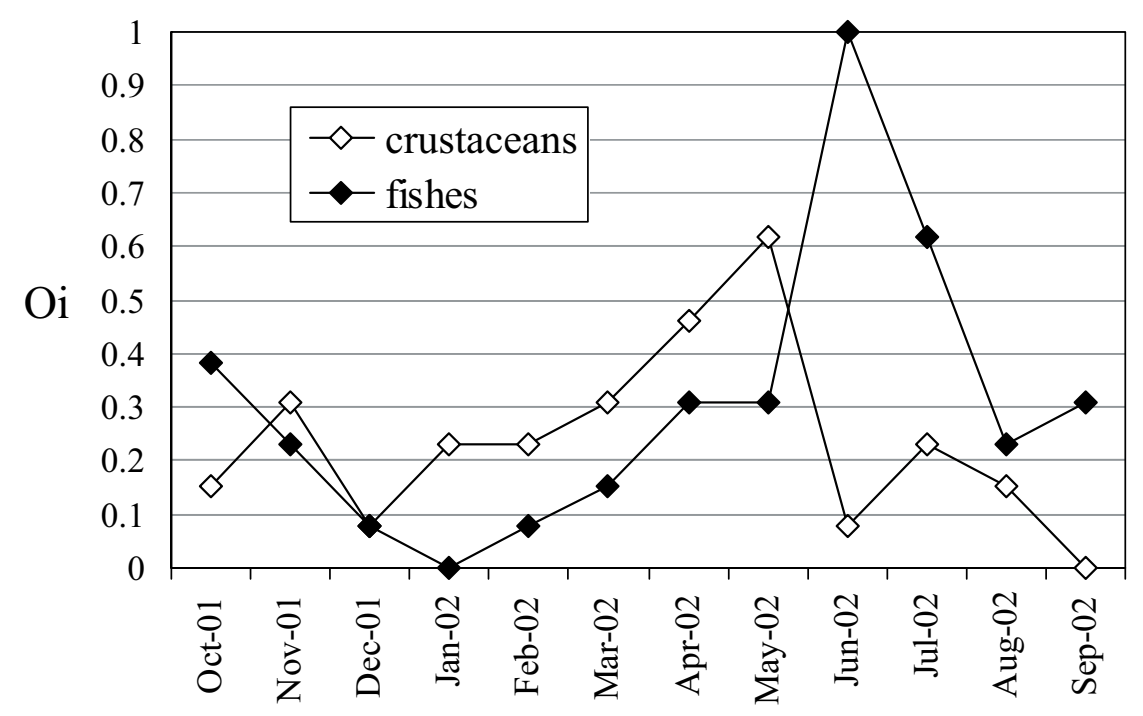

Figure 4

Occurrence frequency $\left(\mathrm{O}_{i}\right)$ values of crustaceans and fish inside the largemouth bass stomach, during the study.

Figure 4

Fréquence d'occurrence $\left(O_{i}\right)$ de crustacés et de poissons dans l'estomac des black-bass échantillonnés pendant l'étude.

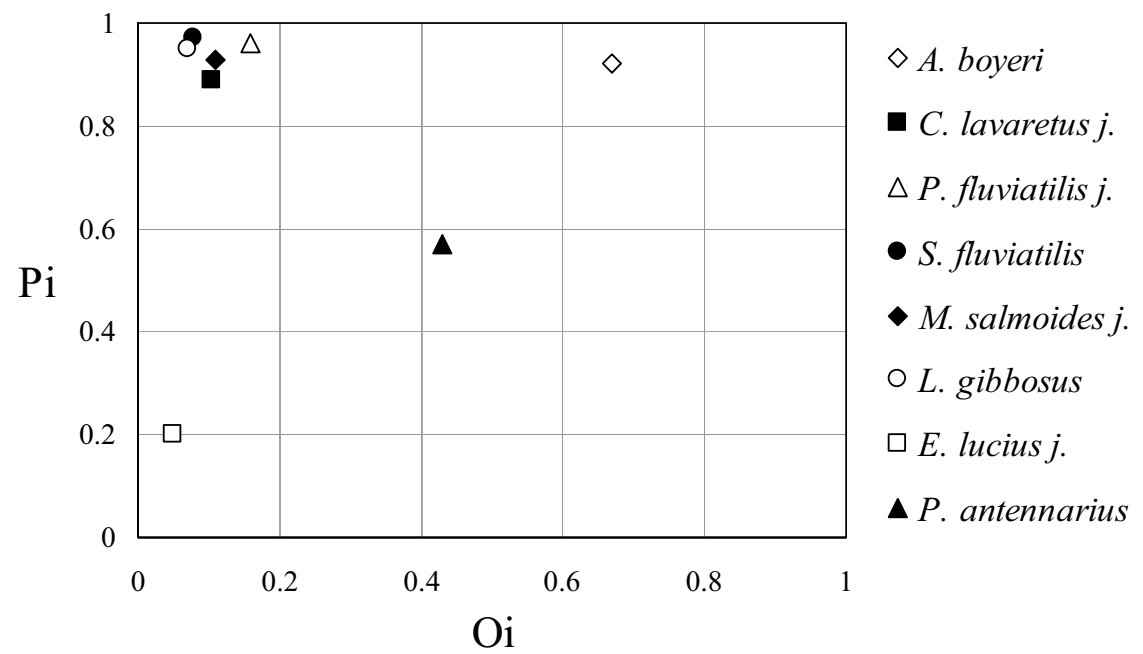

Figure 5

Feeding spectrum of Micropterus salmoides obtained by the Costello analysis. $P_{i}=$ prey-specific abundance; $O_{i}=$ occurrence frequency.

Figure 5

Spectre d'alimentation de Micropterus salmoides obtenu par l'analyse de Costello. $P_{i}=$ abondance des proies spécifiques $; O_{i}=$ fréquence d'évènement. 


\section{Reproduction}

Visceral fat reserves (V.F.R.) were observed in $88.7 \%$ of the females and $77.4 \%$ of the males. Firstly, the coelomic space adjacent to the gonads was filled; then, adipose mass occupied interstices among the other organs.

Of the whole sample, $42.3 \%$ of the specimens showed anomalous gonads. In particular, $18.3 \%$ of the females and $6.6 \%$ of the males showed an atresia of the right gonad, while $5.6 \%$ of the females and $2.2 \%$ of the males of the left gonad. Only two individuals ( 1 female and 1 male), were affected by a total atresia of the gonads.

The ovary development was in an advanced phase between December and February, when the eggs were rich in yolk and lipidic drops. Similarly, the males showed mature gonads between December and February, extending active spermatogenesis until June. The monthly values of the $M$ index for both sexes are shown in Figure 6; the maximum values occurred between December and February, for the females, and between December and June, for the males. The gonadic index shows a similar trend for both sexes (Figure 7).

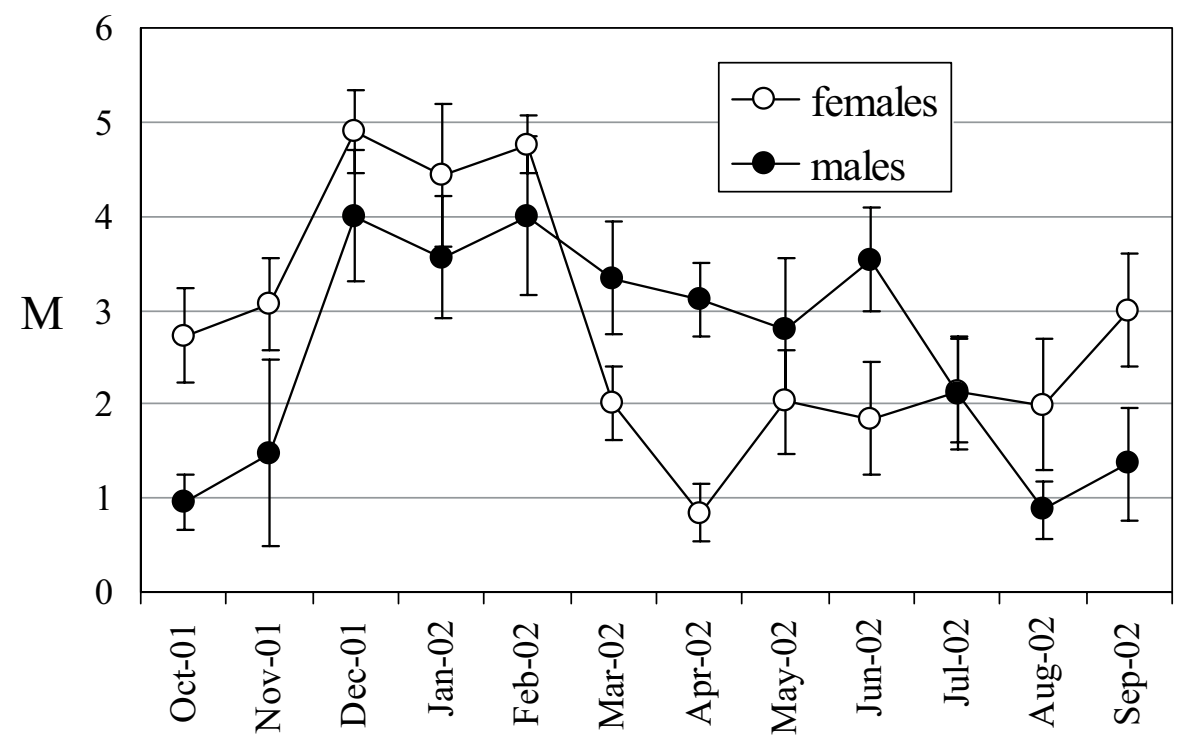

Figure 6

Mean monthly values and standard deviations of the Average Level index (M) during the study period.

\section{Figure 6}

Moyennes mensuelles et déviations standard de l'index du niveau moyen (M) pendant la durée de l'étude. 


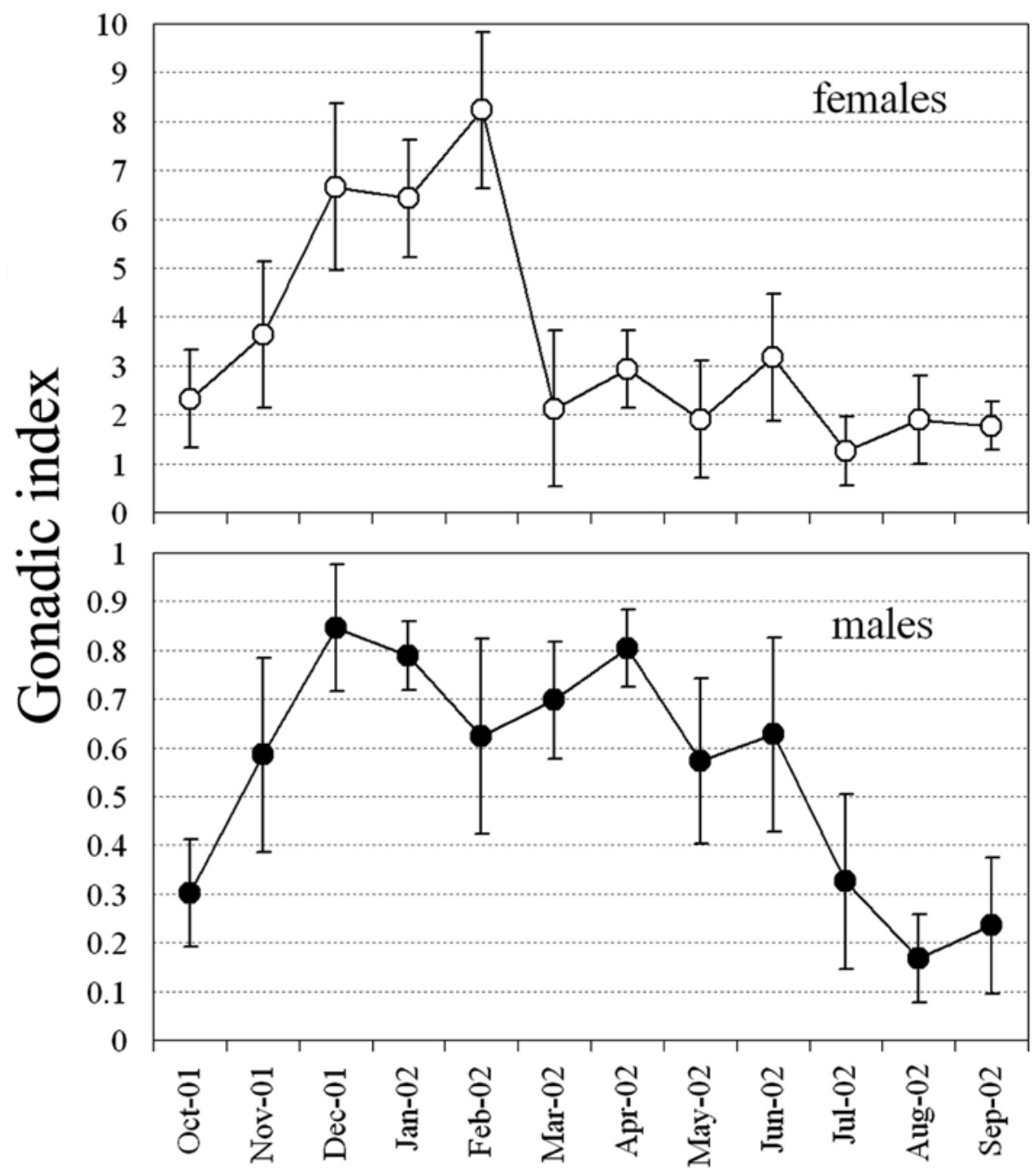

Figure 7

Mean monthly values and standard deviations of the gonadic index, during the study period.

\section{Figure 7}

Moyennes mensuelles et déviations standard de l'index gonadique pendant la durée de l'étude.

A length-frequency analysis using mature specimens was obtained (Figure 8). The minimum size at which mature gametes were identified was 16.2 and $17.4 \mathrm{~cm}$, for the females and the males respectively (both $0+$ ). The $L_{50 \%}$ was reached at $19 \mathrm{~cm} \mathrm{SL}$ for the females and $20 \mathrm{~cm} \mathrm{SL}$ for the males, when the specimens are 1 . 


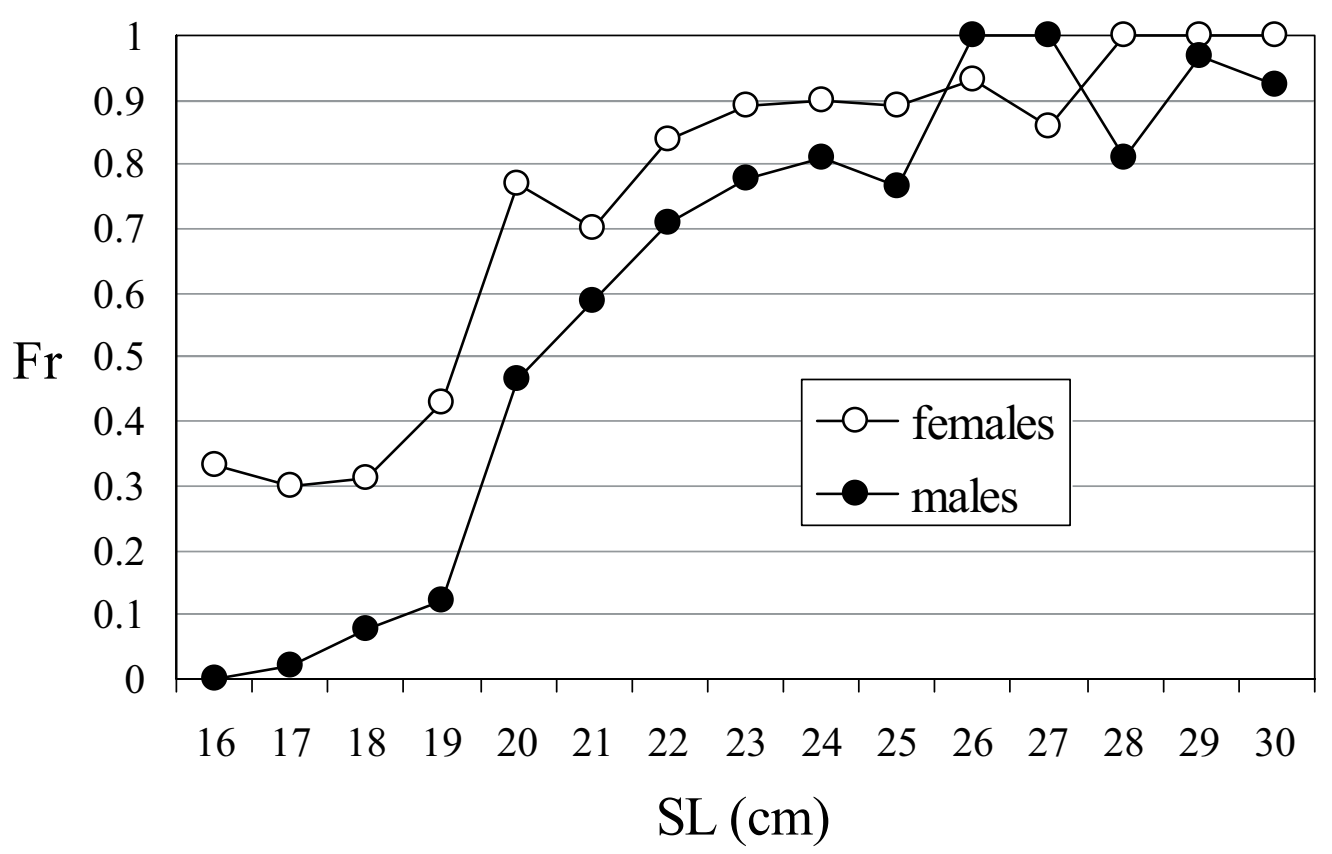

Figure 8

Occurrence frequency (Fr) of specimens having mature gonads, per size-class (SL).

Figure 8

Distribution de fréquence ( $F r)$ des spécimens ayant des gonades matures, par classe de taille (SL).

\section{DISCUSSION}

The sampled population was dominated by the $1+$ age-class. The youngest ageclass $(0+)$ was probably under-represented due to the fishing method used, favouring larger individuals (COWX, 1983), whereas the small number of older specimens $(>3+)$ was probably related to their recent introduction into the lake. In addition, the larger specimens have higher movement ability and the capture efficacy for them was probably low.

The mean sizes at different ages, as well as the slope of the length-weight relationship did not show substantial differences from other Italian studies carried out in lentic waters of Central Italy (ZERUNIAN, 1980; ALESSIO, 1981, 1983; LORENZONI et al., 1996, 2002b). This is probably due to the geographic and ecological similarities of the lakes.

We did not carry out a study on largemouth bass growth performance but, comparing mean sizes at different ages, significant differences did not seem to exist among the results observed in this study and those reported in studies carried out within primary and secondary areal. This indicates a wide ecological plasticity of the species (see LORENZONI et al., 2002b).

In Lake Bracciano, M. salmoides showed a high consumption of fish (especially for A. boyeri), although it was not exclusively piscivorous, having also a high consumption of the decapod Palaemonetes antennarius. Our results agree with the diet described for 
the species in other European studies, with fish being the predominant food item (for bass $>20 \mathrm{~cm}$ in TL) and crustaceans and insects being also frequently eaten (ALESSIO, 1983; RODRIGUEZ-JIMENEZ, 1989; GODINHO and FERREIRA, 1994; NICOLA et al., 1996; GODINHO et al., 1997; GODINHO and FERREIRA, 1998). However, our results contrast with the observations of LORENZONI et al. (2002b) in another Italian lake (Lake Trasimeno), where the main food item was $P$. antennarius and fish were the dominant food item only in the youngest specimens. The number of fish species preyed by bass was also higher in our study when compared with other studies, particularly in the lberian Peninsula where largemouth bass occurs in most river basins (RODRIGUEZ-JIMENEZ, 1989; GODINHO and FERREIRA, 1994; GODINHO et al., 1997; GODINHO and FERREIRA, 1998). Since we are not able to compare the fish resources between Lake Bracciano and other studied areas, due to lack of data in literature upon the fish abundance, we can only suppose that bass showed a preference for $P$. antennarius rather than fish in Lake Trasimeno due to the high availability of shrimps. The low number of preyed fish species in the Iberian Peninsula (frequently the pumpkinseed sunfish) probably reflects also the higher availability of one or few species or reflects the fact that there are no other species of the right size present in the studied systems (RODRIGUEZ-JIMENEZ, 1989; GODINHO and FERREIRA, 1994; GODINHO et al., 1997; GODINHO and FERREIRA, 1998). Probably in Lake Bracciano, $M$. salmoides have a higher number of species available as a trophic resource.

Therefore, $M$. salmoides seems to be an opportunistic predator with an alimentary range depending on the environment and on the feeding resources (HE et al., 1994; HICKLEY et al., 1994; GODINHO et al., 1997; OLSON et al., 1998; LORENZONI et al., 2002b).

The seasonal variation in the bass feeding activity was probably related to the water temperature and to the reduction of the foraging activity during the reproductive period, also observed elsewhere (HEIDINGER, 1974; ALESSIO, 1983; ROSEMBLUM et al., 1994). Foraging activity and food assimilation make it possible to accumulate fat inside the coelomatic cavity, increasing the visceral fat reserves (VFR). This represents a surplus over the natural physiological needs and stimulates the gonadic development (ROSEMBLUM et al., 1994).

With regard to reproduction, the male specimens showed high values of the $M$ index from December to June (with a maximum in the first three months), similar to what was observed by ROSENBLUM et al. (1994) in Florida. But the reproductive period (i.e. when both sexes showed matured gonads) occurred only during 3 months, between December and February, earlier than the period (April and May) described in other studies conducted in temperate zones (ALESSIO, 1981, 1983; LORENZONI et al., 2002b). Bass also presented an early maturation $(1+)$, unusual for the species in temperate latitudes but reported for tropical fast growing populations (e.g. WEYL and HECHT, 1999; BEAMISH et al., 2005; BRITTON and HARPER, 2005; BRITTON and HARPER, 2006). In other Italian studied populations (ALESSIO, 1981, 1983; LORENZONI et al., 2002b) and within the native range (ROSEMBLUM et al., 1994), largemouth bass usually reaches a sexual maturation at age $3+$ and $2+$, for the females and the males respectively.

Bass maturation could be more dependent on the size than on the age. Therefore, the age at maturity (i.e. first reproduction) could vary widely.

Our results suggest that largemouth bass has found a favourable environment and good trophic conditions in Lake Bracciano. In addition, some of the results could reflect its recent introduction, namely the high relative abundance of the younger age classes and the scarcity of older individuals, together with the early maturation. Its recent introduction could explain the diversified feeding habits, reflecting a still reduced influence of largemouth bass on the Lake Bracciano fish community. Studies carried out later would allow a more definitive 
assessment of bass impact upon the autochthonous fish community. Once introduced, an exotic species can create serious problems for the native fish species (HOLCIK, 1991), even more so if the alien species is a successful piscivorous, such as largemouth bass. In fact, several studies have reported that non-native species can seriously affect populations of autochthonous species (WILLIAMSON and FITTER, 1996; HOLCIK, 1991; COX, 1999; LORENZONI et al., 2002a; JERSCKE and STRAYER, 2005).

\section{ACKNOWLEDGEMENTS}

This research has been carried out thanks to the funds that have been put at disposal by the Province of Rome, Caccia e Pesca, Dipartimento V Servizio 3. Moreover we sincerely wish to thank two anonymous reviewers for providing useful comments and suggestions to improve the manuscript, and Dr M. KENYON for revising the manuscript language.

\section{REFERENCES}

ALESSIO G., 1981. Ricerche sul persico trota, Micropterus salmoides (Lacépède) nel bacino medio superiore del fiume Po. Natura, Soc. Ital. Sci. Nat. Museo civico stor. Nat. Acquario civ. Milano, 72, 197-200.

ALESSIO G., 1983. Le black-bass, Micropterus salmoides (Lacép.) dans les eaux italiennes. Un antagoniste du brochet? BFPP, Bull. Fr. Pêche Piscic., 292, 1-17.

AMUNDSEN P.A., GABLER H.M., and STALDVIK F.J., 1996. A new approach to graphical analysis of feeding strategy from stomach contents data - modification of the Costello method. Journal of Fish Biology, 48, 607-614.

BAGLINIERE J.L., LE LOUARN H., 1987. Caractéristiques scalimétriques des principales espèces de poisson d'eau douce de France. BFPP, Bull. Fr. Pêche Pisc., 306, 139.

BEAMISH C.A., BOOTH A.J., DEACON N., 2005. Age, growth and reproduction of largemouth bass, Micropterus salmoides, in Lake Manyame, Zimbabwe. African Zoology, 40, 63-69.

BELLINI A., PIETROMARCHI A., GIBERTINI G., MORGANA G.J., 2001. Study of the fish fauna for the protection and monitoring of the watercourses in the Protected Natural Areas of the Municipality of Rome. Journal of Freshwater Biology, 30, 145-150.

BREDER C.M., ROSEN D.E., 1966. Modes of reproduction in fishes. Natural History press, New York, $941 \mathrm{p}$.

Britton J.R., Harper D.M., 2005. Preliminary investigations into the age and growth of a largemouth bass population in an equatorial lake. J. East Afr. Nat. Hist., 94, 363369.

Britton J.R., Harper D.M., 2006. Length-weight relationships of fish species in the freshwater rift valley lakes of Kenya. J. Appl. Ichth., 22, 334-336.

CARLANDER, K.D., 1977. Handbook of freshwater fishery biology. 2. Life history data on centrarchid fishes of the United States and Canada. Iowa State University Press, Ames, lowa.

CLERICI F., TANCIONI., PENNELLI B., GIBERTINI G., CATAUDELLA S., 2007. Effects of impondement and pollution upon fish assemblages of the low stretch of Tiber River. Italian Journal of Zoology, in press.

COSTELLO M.J., 1990. Predator feeding strategy and prey importance: a new graphical analysis. Journal of Fish Biology, 36, 261-263. 
COWX I.G., 1983. Review of methods of estimating fish population size from survey removal data. Fish. Manag., 14, 67-82.

COX G.W., 1999. Alien Species in North America and Hawaii: impacts on natural ecosystem. Island press, Washington, D.C., 387 p.

Crooks J.A. 2002. Characterizing ecosystem-level consequences of biological invasions: the role of ecosystem engineers. Oikos, 97, 153-166.

EWEL J.J., O’DOWD D.J., BERGELSON J., DAEHLER C.C., D'ANTONIO C.M., GOMEZ D., GORDON D.R., HOBBS R.J., HOLT A., HOPPER K.R., HUGHES C.E., LAHART M., LEAKEY R.R.B., LEE W.G., LOOPE L.L., LORENCE D.H., LOUDA S.M., LUGO A.E., MCEVOY P.B., RICHARDSON D.M., VITOUSEK P.M., 1999. Deliberate introductions of species: research needs. Bioscience, 49, 619-630.

GARCIA-BERTHOU E., 2002. Ontogenetic diet shifts and interrupted piscivory in introduced largemouth bass (Micropterus salmoides). Internat. Rev. Hydrobiol., 87 (4), 353-363.

GIBERTINI G., SCALICI M., VIGNOLI L., MOCCIA G., MATTINA F., 2004. I pesci del Lago di Bracciano. La comunità ittica, la pesca e il ripopolamento. Provincia di Roma. Assessorato alle Politiche dell'Agricoltura, Ambiente e Protezione Civile, 32 p.

GODINHO F.N., FERREIRA M.T., 1994. Diet composition of largemouth black bass, Micropterus salmoides (Lacépède), in souther portuguese reservoirs: its relation to habitat characteristics. Fish. Manage. Ecol., 1, 129-137.

GODINHO F.N., FERREIRA M.T., 1998. Spatial variation in diet composition of pump kinseed sunfish, Lepomis gibbosus, and largemouth bass, Micropterus salmoides, from a Portuguese stream. Folia Zool., 47, 205-213.

GODINHO F.N., FERREIRA M.T., CORETS R.V., 1997. The environment basis of diet variation in pumpkinseed sunfish, Lepomis gibbosus, and largemouth bass, Micropterus salmoides, along an Iberian river basin. Environ. Biol. Fish., 50, 105115.

HE X., HODGSON J.R., KITCHELL J.F., WRIGHT R.A., 1994. Growth and diet composition of largemouth bass (Micropteurs salmoides) from four experimental lakes. Verh. Int. Ver. Limnol., 25, 92-97.

HEIDINGER R.C., 1974. Life history and biology of the largemouth bass. In: STROUD, R.H. \& CLEPER, H. (eds.). Black bass biology and management. Sport Fishing Institute, Washington, D.C., 11-20.

HEIDINGER R.C., 1976. Synopsis of biological data on the largemouth bass Micropterus salmoides (Lacépède, 1802). Fish. Synopsis, 115, 1-85.

HICKLEY P., NORTH R., MUCHIRI S.M., HARPOER D.M., 1994. The diet of largemouth bass, Micropterus salmoides, in Lake Navaisha, Kenya. J. Fish Biol. 44, 607-619.

HOLCIK J., 1991. Fish introduction in Europe with particular reference to its central and eastern part. Can. J. Fish. Aquat. Sci., 48, 13-23.

JERSCKE J.M., STRAYER D.L., 2005. Invasion success of vertebrates in Europe and North America. Proc. Nat. Acad. Sci. USA, 102, 7198-7202.

KEAST A., 1985. The piscivory feeding guild of fishes in small freshwater ecosystems. Environmental Biology of Fishes, 12, 119-129.

KEAST A., WEBB D., 1966. Mouth and body form relative to feeding ecology in the fish fauna of a small lake, Lake Opinicon, Ontario. Journal of the Fisheries Research Board of Canada, 23, 1845-1874. 
Kolar C.S., Lodge D.M., 2001. Progress in invasion biology: predicting invaders. Trends Ecol. Evol., 16, 199-204.

LADIGES W., VOGT D., 1979. Die Süsswasserfische Europas. Parey Hamburg, II ed., $231 \mathrm{p}$.

LORENZONI M., CAROSI A., DORR A.J.M., GIOVINAZZO G., PETESSE M.L., MEARELLI M., 1996. Accrescimento di Micropterus salmoides (Lacépède) nel lago Trasimento e nell'invaso di Montedoglio. Atti VI Convegno AllAD, 177-188.

LORENZONI M., CORBOLLI M., DORR A.J.M., GIOVINAZZO G., SELVI S., MEARELLI M., 2002a. Diets of Micropterus salmoides Lac. and Esox lucius L. in Lake Trasimeno (Umbria, Italy) and their diet overlap. Bull. Fr. Pêche Pisc., 365-366, 537-547.

LORENZONI M., DORR A.J.M., ERRA R., GIOVINAZZO G., MEARELLI M., SELVI S., $2002 \mathrm{~b}$. Growth and reproduction of largemouth bass (Micropterus salmoides Lacépède, 1802) in Lake Trasimeno (Umbria, Italy). Fish. Res., 56, 89-95.

MACK R.N., SIMBERLOFF D., LONDSDALE W.M., EVANS H., CLOUT M., BAZZAZ F.A., 2000. Biotic invasions: causes, epidemiology, global consequences, and control. Ecological Applications, 10 (3), 689-710.

MAIO G., 2002. Specie ittiche alloctone d'acqua dolce: evoluzione storica e stato attuale in Italia. Atti del Convegno Nazionale" La gestione delle specie alloctone in Italia. II caso della nutria e del gambero rosso della Louisiana." Firenze, 24-25 Ottobre, 81-88.

MARINELLI A., SCALICI M., GIBERTINI G., 2004. L'introduzione del persico trota (Micropterus salmoides, Lacépède 1802) nel lago di Bracciano (Lazio). Osservazioni preliminari. Biol. Amb., 18 (1), 251-254.

NICOLA G., ALMODOVAR A., ELVIRA B., 1996. The diet of introduced largemouth bass, Micropterus salmoides, in the natural park of the Ruidera Lakes, Central Spain. Pol. Arch. Hydrobiol., 43, 179-184.

NIKOLSKY G.V., 1963. The ecology of fish. Acad. Press, London, XV + $351 \mathrm{p}$.

OLSON M.H., 1996. Ontogenetic niche shifts in largemouth bass: variability and consequences for first-year growth. Ecology, 77, 179-190.

OLSON M.H., CARPENTER S.R., CUNNINGHAM P., GANFY S., HERWIG B.R., NIBBELINK N.P., PELLET T., STORLIE C., TREBITZ A.S., WILSON K.A., 1998. Managing macrophytes to improve fish growth: a multi-lake experiment. Fisheries, 23, 6-12.

PHILLIPS J.M., JACKSON J.R., NOBLE R.L., 1995. Hatching date influence on age-specific diet and growth of age-0 largemouth bass. Trans. Amer. Fish. Soc., 124, 370-379.

RAHEL F.J., 2000. Homogenization of fish faunas across the united states. Science, 288, 854-856.

RODRIGUEZ-JIMENEZ A.J., 1989. Habitos alimenticios de Micropterus salmoides (Pisces: Centrarchidae) Lepomis gibbosus (Pisces: Centrarchidae) y Gambusia affinis (Pisces: Poecilidae) en las orillas del embalse de prosperina (Extremadura, España). Limnética, 5, 13-20.

ROSENBLUM P.M., BRANDT T.M., MAYES K.B., HUTSON P., 1994. Annual cycles of growth and reproduction in hatchery-reared Florida largemouth bass, Micropterus salmoides floridanus, raised in forage or pelleted diets. Journal of Fish Biology, 44, 1045-1059.

SPEDICATO M.T., CANNAS A., 2000. La pesca responsabile. In: CATAUDELLA S. \& CARRADA G.C. (eds.), Un mare di risorse, introduzione alla conservazione ed alla gestione delle risorse ittiche, 67-135. 
TORTONESE E., 1975. Osteicthyes, parte II - Fauna d'Italia, Calderoni, Bologna, XI: $18+636 \mathrm{p}$.

WELCOMME R.L., 1992. A history of international introductions of inland aquatic species. ICES mar. Sci. Symp., 194, 3-14.

WERNER E.E., HALL D.J., LAUGHLIN D.R., WAGNER D.J., WILSMANN L.A., FUNCK F.C., 1977. Habitat partioning in a freshwater fish community. J. Fish. Res. Bd Can., 34, 360-370.

WEYL O.L.F., Hecht T., 1999. A successful population of largemouth bass, Micropterus salmoides, in a subtropical lake in Mozambique. Environ. Biol. Fish., 54, 53-66.

WILLIAMSON M., FITTER A., 1996. The varying success of invaders. Ecology, 77, 16661670.

ZERUNIAN S., 1980. Accrescimento in condizioni naturali ed intensive del persico trota (Micropterus salmoides) nel basso Lazio. Riv. ital. Piscic. Ittiopatol, 15, 13-16.

ZERUNIAN S., 2002. Condannati all'estinzione? Biodiversità, biologia, minacce e strategie di conservazione dei Pesci d'acqua dolce indigeni in Italia. Edagricole, 220 p. 
